\title{
Reframing school bullying: The question of power and its analytical implications
}

Paul Horton

The self-archived postprint version of this journal article is available at Linköping University Institutional Repository (DiVA):

http://urn.kb.se/resolve?urn=urn:nbn:se:liu:diva-161466

N.B.: When citing this work, cite the original publication.

Horton, P., (2019), Reframing school bullying: The question of power and its analytical implications, Power and Education, 9(1), 89-121. https://doi.org/10.1177/1757743819884955

Original publication available at:

https://doi.org/10.1177/1757743819884955

Copyright: Symposium Journals

http://www.symposium-journals.co.uk/ 


\title{
Reframing School Bullying: The Question of Power and its Analytical Implications
}

\author{
Paul Horton
}

Department of Behavioural Sciences and Learning, Linköping University, Linköping, Sweden

Department of Behavioural Sciences and Learning, Linköping University, Linköping SE58183, Sweden.paul.horton@liu.se

\begin{abstract}
The past 30 years has seen a significant increase in research interest and public discussion about school bullying and an associated diversification in perspectives on the issue. In attempting to bridge divisions between different research paradigms, there have been calls for cross-paradigmatic dialogue. In this short think piece, I seek to facilitate such dialogue by addressing the question of power and considering its analytical implications for school bullying research, antibullying initiatives, and education more generally. In doing so, I relate the discussion to the various systems of the widely used social-ecological framework. I argue that a focus on power suggests a need for more consideration of the various levels of the social-ecological framework, more consideration of the importance of social difference, and more consideration of the importance of the school context and issues of power and resistance therein.
\end{abstract}

\section{Keywords}

Bullying, school, power, resistance, education 


\section{Introduction}

The problem of school bullying has been the subject of increasing research interest and public discussion since the late 1960s and the work of Heinemann $(1969,1972)$ and Olweus $(1973)$ in Sweden. Indeed, the past 30 years has seen an exponential growth in the number of research articles published about school bullying (Hymel and Swearer, 2015; Volk et al., 2017). Researchers have pointed to different perspectives on school bullying, contrasting individual-focused first-order perspectives with second-order perspectives that are more focused on social processes (Kousholt and Fisker, 2015; Schott and Søndergaard, 2014; Thornberg, 2015), and have also highlighted the range of academic fields from which such perspectives stem (Thornberg et al., 2018). Thornberg (2015) suggests that the socialecological framework may provide a meeting point at which these different perspectives can enter into dialogue, as it provides the theoretical space for considering both first-order and second-order perspectives. However, a potential sticking point for such dialogue is the question of power and how it is understood. In this short think piece, I reframe school bullying in relation to the social-ecological framework by addressing the question of power and considering its analytical implications for school bullying research, anti-bullying initiatives, and education more generally.

\section{The Question of Power}

Eriksson (2001) argued that a major problem with school bullying research is that the field is one that is dominated by exclamation marks and lacking in question marks. While a number of questions have certainly been raised since then, his critique is still highly relevant today. Walton (2011: 134), for example, argues that the theoretical foundations upon which much bullying research is built are 'fundamentally flawed'. In essence, we do not have enough understanding of the problem, and yet we push through anti-bullying legislation and anti- 
bullying programmes, and publish recommendations to schools about how best to deal with the problem (Walton, 2015). In considering the flaws in the theoretical foundations of bullying research, it is useful to consider the criteria upon which most definitions of bullying are generally based: aggressive intention (i.e. the intention to harm), repetition, and a power imbalance (Menesini and Salmivalli, 2017; Volk et al., 2017). While researchers have questioned the aggressive intention behind bullying and the repetition involved, most seem to agree that bullying necessarily involves a power imbalance of some form (Volk et al., 2014). In 1993, for example, Olweus wrote:

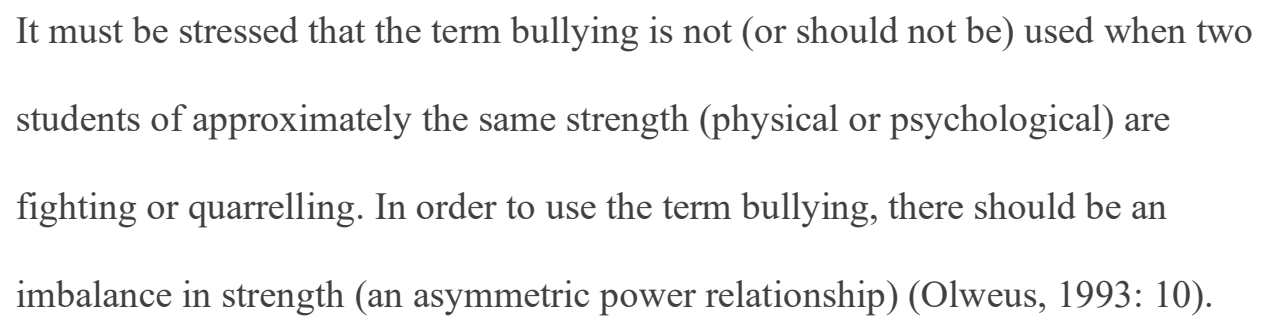

So, what does an asymmetric power relationship look like? Is it simply when someone has greater strength than another? The perceived necessity of a power imbalance raises a number of fundamental questions that have yet to be adequately addressed within the field of school bullying research. Questions such as: What is power? And how is power exercised? As Vaillancourt et al. (2003) point out, despite the centrality of power to bullying relations, there has been little consideration of how bullying relates to power, or indeed how power is connected to the interactions between individuals and the social context. A number of power theorists have pointed out that power is not simply an attribute but is rather an ability or capacity to induce change (e.g. Foucault, 1982; Giddens, 1984; Lukes, 2005). As Lukes (2005: 109) puts it, 'power is a dispositional concept, identifying an ability or capacity, which may or may not be exercised.' In explaining the capacity of power, Giddens (1984: 14) suggests that power is the "capability to "make a difference"', while Foucault (1982: 789) 
refers to power as a form of government, whereby one is able to 'conduct' the 'conduct' of others.

In considering the exercise of power, Vaillancourt et al. (2003: 159) distinguish between two forms of social power: 'explicit social power', which is connected to aspects such as size and strength, and 'implicit social power', which is connected to aspects such as popularity and social status. While size and strength are relatively stable attributes, popularity and status are socially contingent and need to be performed and 'realized' (Goffman, 1990: 81). As Volk et al. (2014: 333) note:

\section{Power is not solely a property of relatively stable, individual factors such as a person's size and strength, but also of situational, social, or environmental variables that result in a dynamic ecology that can change the power dynamic.}

Giddens (1968: 268) states that 'power extends as deeply into the roots of social life as do values or norms' and that norms and power are in a relation of interdependency. In a similar way, Foucault (1982: 792) suggests that power is exercised in relation to the 'system of differentiations which permits one to act upon the actions of others.' Foucault (1982) argues that every power relationship draws on such differentiations and at the same time serves to reinforce those differentiations. In understanding power and bullying, then, it is necessary to broaden out from the individuals involved, and their particular attributes, to consider how they come to exercise power over others during social interactions. One way in which to do this is by considering bullying in relation to the social-ecology within which those individuals and their interactions are located.

\section{The Social-ecology of Bullying}

The work of Bronfenbrenner $(1977,1979)$ has provided a useful means through which to expand discussions of school bullying, not only to include the social context, but also the 
institutional and societal contexts within which social interactions are located.

Bronfenbrenner (1979) suggests that the ecological environment can be understood in terms of a nesting doll, with the individual in the centre, located within the concentric structures of microsystems, mesosystems, exosystems, and macrosystems. A number of bullying researchers have utilized the social-ecological framework in their work (e.g. Espelage and Swearer, 2010; Hong and Espelage, 2012). However, there has been a tendency to focus on the individual, the microsystem and, to a lesser degree, the mesosystem; leaving the exosystem and macrosystem largely out of the picture (Carrera et al., 2011; Thornberg, 2015).

Starting with the individual level, there has been a tendency to characterize the individuals involved in bullying (either directly or indirectly) as 'bullies' or 'victims', or as various types of 'bystanders' (Olweus, 1993; Salmivalli, 1999). Such typologies run the risk of typecasting. As Goffman (1990) points out, people seek to present themselves in particular ways, and thus inevitably engage in impression management. To assume that the presentation of self is a direct expression of the characteristics of the individual obscures the different functions such performances play in social interactions. While some researchers have argued that bullying is used by individuals to achieve social dominance (e.g. Goodboy et al., 2016), Jacobson (2010) argues that dominance is not necessarily the aim of bullying but rather the means through which individuals strive to produce a public identity.

Researchers have tended increasingly to focus on the microsystem as that system wherein school bullying takes place. In discussing the presentation of self, Goffman (1990: 15) argued that a key concern for those involved in social interactions is the issue of controlling 'the conduct of the others'. As Goffman (1990) put it, such control is achieved through impression management, whereby individuals seek to manage the impression they give off to others, as well as how those others act in accordance with the impression received. As an example of such attempts at control, some researchers have pointed to the importance 
of laughter (Jacobson, 2010; Søndergaard, 2018). Jacobson (2010: 40), for example, suggests that mockery 'creates boundaries between us and the other' and provides a means of protecting against the fear of being laughed at by the other; that is, the fear of having our own presentation of self undermined through the laughter of others. Such attempts at control are tied up with processes of inclusion and exclusion and can be linked to what Søndergaard (2012) terms 'social exclusion anxiety'; that is, a fear of potentially being socially excluded, which 'smoulders beneath the surface when people interact' (Søndergaard, 2012: 360).

If we move on to the mesosystem, it is also important to consider the 'interrelations among two or more settings' within which individuals participate (Bronfenbrenner, 1979: 25), such as during transitions from middle school to high school, or in spaces such as school canteens, school playgrounds, school gymnasiums, or school buses. This may occur directly in the case of 'multisetting participation' or indirectly through communication and the exchange of social information (Bronfenbrenner, 1979: 209). Such interrelations may negatively affect an individual's ability to manage impressions and may impact the extent to which they are able to exercise power.

As I have already suggested, there has been very little focus on the exosystem, which is essentially an extension of the mesosystem, expanded to include not only those settings of which individuals are a part, but also those settings where they are not included (Bronfenbrenner, 1979). Examples include meetings between parents and teachers or between teachers and other school staff, where decisions may be taken without the input of those affected but may impact upon their social relations in myriad ways, such as school antibullying policies, seating plans, classroom rules, or playground rules.

Moving out to the macrosystem level, and its legal frameworks and socio-cultural norms, it is possible to consider the ways in which bullying behaviours are influenced by education laws, anti-discrimination laws, and norms related to age, gender, sexuality, 
ethnicity, religion, class, and disability. A number of researchers have pointed to the importance of societal and social norms related to social difference and have argued that rather than perceiving bullying as pathological behaviour, it may make more sense to understand it as normative behaviour (Bansel et al., 2009; Davies, 2011; Pascoe, 2013; Ringrose and Renold, 2010). While researchers utilizing the social-ecological framework have noted the importance of the macrosystem, they have also pointed to the difficulties of studying it empirically (Espelage and Swearer, 2010). This perhaps says something about the dominant methods and theoretical foundations of the field, and about the continued focus on so-called 'evidence-based' knowledge (Schott and Søndergaard, 2014).

\section{The Power of Schooling}

It should also be noted that Bronfenbrenner $(1977,1979)$ was highly critical of psychology's tendency to focus on the individual at the expense of the environment, and suggested that in thinking about the environment, it is important to not only think about it in terms of the social environment, but also in terms of the physical environment. So, what of the school in school bullying? There has been surprisingly little consideration of this, despite the word 'school' making up half of the term 'school bullying'. The importance of the school context has been noted by a number of researchers (e.g. Duncan, 2013; Eriksson et al., 2002; Yoneyama, 2015; Yoneyama and Naito, 2003). Duncan (2013), for example, points to four key aspects of schooling - compulsion, compression, control, and competition - all of which can be discussed in terms of power and the associated resistance of those subjected to it.

A number of power theorists have highlighted the interrelations between power and resistance. Foucault (1998: 95), for example, argues that power and resistance are two sides of the same coin and that '[w] here there is power, there is resistance'. Giddens (1982: 197-198) refers instead to a 'dialectic of control', whereby: 
[I]n any relationship which may be involved in a social system, the most seemingly 'powerless' individuals are able to mobilise resources whereby they carve out 'spaces of control' in respect of their day-to-day lives and in respect of the activities of the more powerful.

The aspects of schooling pointed out by Duncan (2013) may inadvertently serve to reinforce certain aspects of the system of differentiations and/or reduce the ability of some individuals to carve out spaces of control. Compulsion, for example, means that students cannot leave if and when they feel the need. Compression means that there are often large numbers of students crammed into relatively restricted spaces and that there is thus limited scope for students to carve out spaces of control for themselves. Control, likewise, restricts the ability of students to carve out spaces of control because of timetabling, seating plans, and classroom rules about staying in your seat, not speaking unless told to, and so on. As Jacobson (2010: 49) points out, competition contributes to the system of differentiations by creating 'grids of hierarchy' through the distribution of As and Bs, or first places and second places, for example.

\section{Power and its Analytical Implications}

So, what are the implications of this? Perhaps, as Walton (2015) argues, we need to go back to the proverbial drawing board. Perhaps, we need to ask questions about what we have taken for granted, to broaden our focus out from the behaviour of individuals or groups of individuals, and their aggressive acts, and ask ourselves questions about how social interactions within schools are reflective of and serve to generate and uphold social norms. If we reconsider what we mean by power, then what does this mean for bullying research, antibullying work, and for education more generally? For bullying research, it suggests the need for a broader focus that poses questions about the taken-for-given, that considers the various 
systems of the social-ecological framework, and which investigates the importance of social norms and the system of differentiations that facilitates bullying behaviour. It also suggests the need for a move away from simply asking about 'bullying', as if its 'nebulous' character can be captured in an academic 'butterfly net' (Valentine, 2014: 88). Likewise, for antibullying work, it suggests the need for a shift away from a juridical focus on negative actions and the punishment of 'bullies' towards increased focus on the importance of social norms and social relations. For education more generally, it suggests the need for addressing the importance of social difference, not in terms of tolerance but in terms of understanding, and for creating school environments that facilitate openness and inclusiveness (Davies, 2011; Jacobson, 2007; Pascoe, 2013; Walton, 2015). Related to this, it suggests a need to consider the importance of the school context, and the ways in which students may resist and seek to "carve out "spaces of control"' (Giddens, 1982: 197-198). Such attempts may take the form of 'secondary adjustments', which are used to get around institutional demands and expectations (Goffman, 1991), 'rituals of resistance' such as off-topic talk, joking or teasing (McLaren, 1985), 'hidden transcripts' enacted behind the back of authority (Scott, 1990), or the stigmatization (Goffman, 1986; Huggins, 2016) of those who align, or fail to align, themselves with schooling.

\section{Funding details}

This work was funded by the Swedish Research Council (Vetenskapsrådet) for the project Bullying arenas: A social-ecological investigation of school bullying (2017-03604).

\section{References}

Bansel P, Davies B, Laws C, et al. (2009) Bullies, bullying and power in the contexts of schooling. British Journal of Sociology of Education 30(1): 59-69. 
Bronfenbrenner U (1977) Toward an experimental ecology of human development. American Psychologist 32(7): 513-531.

Bronfenbrenner U (1979) The Ecology of Human Development: Experiments by Nature and Design. Cambridge: Harvard University Press.

Carrera MV, DePalma R and Lameiras M (2011) Towards a more comprehensive understanding of bullying in school settings. Educational Psychology Review 23: 479499.

Davies B (2011) Bullies as guardians of the moral order or an ethic of truths? Children \& Society 25(4): 278-286.

Duncan N (2013) 'If you tolerate this, then your children will be next.' Compulsion, compression, control, and competition in secondary schooling. International Journal on School Disaffection 10(1): 29-45.

Eriksson B (2001) Mobbning: En sociologisk diskussion [Bullying: A sociological discussion]. Sociologisk Forskning 2: 8-43.

Eriksson B, Lindberg O, Flygare E, et al. (2002) Skolan - en arena för mobbning [The School - An Arena for Bullying]. Stockholm: Skolverket.

Espelage DL and Swearer SM (2010) A social-ecological model for bullying prevention and intervention. Understanding the impact of adults in the social ecology of youngsters. In: Jimerson SR, Swearer SM and Espelage DL (eds) Handbook of Bullying in Schools: An International Perspective. New York: Routledge, pp. 61-72.

Foucault M (1982) The Subject and Power. Critical Inquiry 8(4): 777-195.

Foucault M (1998) The Will to Knowledge: The History of Sexuality 1. London: Penguin. Giddens A (1968) 'Power' in the Recent Writings of Talcott Parsons. Sociology 2(3): 257272. 
Giddens A (1982) Power, the Dialectic of Control and Class Structuration. In: Giddens A (ed) Profiles and Critiques in Social Theory. Contemporary Social Theory. London: Palgrave, pp. 197-214.

Giddens A (1984) The Constitution of Society: Outline of the Theory of Structuration. Cambridge: Polity Press.

Goffman E (1986) Stigma: Notes on the Management of Spoiled Identity. New York: Touchstone.

Goffman E (1990) The Presentation of Self in Everyday Life. London: Penguin.

Goffman E (1991) Asylums: Essays on the Social Situation of Mental Patients and Other Inmates. London: Penguin.

Goodboy AK, Martin MM and Rittenour CE (2016) Bullying as a display of social dominance orientation. Communication Research Reports 33(2): 159-165.

Heinemann PP (1969) Apartheid. Liberal debatt 22(2): 3-14.

Heinemann PP (1972) Mobbning: Gruppvåld bland barn och vuxna [Bullying: Group violence among children and adults]. Stockholm: Natur och Kultur.

Hong JS and Espelage DL (2012) A review of research on bullying and peer victimization in school: an ecological system analysis. Aggression and Violent Behaviour 17: 311-322.

Huggins M (2016) Stigma is the origin of bullying. Journal of Catholic Education 19(3): 166196.

Hymel S and Swearer SM (2015) Four decades of research on school bullying: An introduction. American Psychologist 70(4): 293-299.

Jacobson RB (2007) A lost horizon: the experience of an other and school bullying. Studies in Philosophy and Education 26: 297-317.

Jacobson RB (2010) A place to stand: Intersubjectivity and the desire to dominate. Studies in Philosophy and Education 29: 35-51. 
Kousholt K and Fisker TB (2015) Approaches to reduce bullying in schools - A critical analysis from the viewpoint of first- and second-order perspectives on bullying. Children \& Society 29(6): 593-603.

Lukes S (2005) Power: A Radical View. Second Edition. Basingstoke: Palgrave Macmillan. McLaren PL (1985) The ritual dimensions of resistance: Clowning and symbolic inversion. Journal of Education 167(2): 84-97.

Menesini E and Salmivalli C (2017) Bullying in schools: the state of knowledge and effective interventions. Psychology, Health \& Medicine 22: 240-253.

Olweus D (1973) Hackkycklingar och översittare: forskning om skolmobbning [Whipping boys and bullies: research on school bullying]. Stockholm: Almqvist \& Wiksell. Olweus D (1993) Bullying at School: What we know and what we can do. Malden, MA: Blackwell.

Pascoe CJ (2013) Notes on a sociology of bullying: Young men's homophobia as gender socialization. QED: A Journal in GLBTQ Worldmaking Inaugural Issue: 87-104.

Ringrose J and Renold E (2010) Normative cruelties and gender deviants: the performative effects of bullying discourses for girls and boys in school. British Educational Research Journal 36(4): 573-596.

Salmivalli C (1999) Participant role approach to school bullying: implications for interventions. Journal of Adolescence 22: 453-459.

Scott, JC (1990) Domination and the Arts of Resistance: Hidden Transcripts. New Haven: Yale University Press.

Schott RM and Søndergaard DM (2014) Introduction: new approaches to school bullying. In Schott RM and Søndergaard DM (eds) School Bullying: New Theories in Context. Cambridge: Cambridge University Press, pp. 1-18. 
Søndergaard, DM (2012) Bullying and social exclusion anxiety in schools. British Journal of Sociology of Education 33(3): 355-372.

Søndergaard, DM (2018) The thrill of bullying. Bullying, humour and the making of community. Journal for The Theory of Social Behaviour 48(1): 48-65.

Thornberg R (2015) The social dynamics of school bullying: The necessary dialogue between the blind men around the elephant and the possible meeting point at the socialecological square. Confero: Essays on Education, Philosophy and Politics 3(2): 161203.

Thornberg R, Baraldsnes D and Saeverot H (2018) In search of a pedagogical perspective on school bullying. Nordic Studies in Education 38(4): 289-301.

Vaillancourt T, Hymel S and McDougall P (2003) Bullying is power. Journal of Applied School Psychology 19(2): 157-176.

Valentine DS (2014) A critical foundations analysis of 'The Bully' in Canada's schools. Radical Pedagogy 11(2).

Volk AA, Dane AV and Marini ZA (2014) What is bullying? A theoretical redefinition. Developmental Review 34(4): 327-343.

Volk AA, Veenstra R and Espelage DL (2017) So you want to study bullying? Recommendations to enhance validity, transparency, and compatibility of bullying research. Aggression and Violent Behavior 36: 34-43.

Walton G (2011) Spinning our wheels: Reconceptualizing bullying beyond behaviour-focused approaches. Discourse: Studies in the Cultural Politics of Education 32(1): 131-144.

Walton G (2015) Bullying and the philosophy of shooting freaks. Confero: Essays on Education, Philosophy and Politics 3(2): 17-35.

Yoneyama S (2015) Theorizing school bullying: Insights from Japan. Confero: Essays on Education, Philosophy and Politics 3(2): 120-160. 
Yoneyama S and Naito A (2003) Problems with the paradigm: The school as a factor in understanding bullying (with special reference to Japan). British Journal of Sociology of Education 24(3): 315-330. 